\title{
Preservation of the Endogenous Antioxidants in Low Density Lipoprotein by Ascorbate but Not Probucol during Oxidative Modification
}

\author{
Ishwarlal Jialal and Scott M. Grundy \\ Center for Human Nutrition, Departments of Clinical Nutrition, Internal Medicine, and Biochemistry, \\ University of Texas Southwestern Medical Center at Dallas, Dallas, Texas 75235
}

\begin{abstract}
Several lines of evidence indicate that the oxidative modification of low density lipoproteins (LDL) may provide an important link between plasma LDL and the genesis of the atherosclerotic lesion. Ascorbate is an important water-soluble, chainbreaking antioxidant in humans. Probucol, a lipid-soluble antioxidant drug has been shown to retard the progression of atherosclerosis. The aim of the present study was to compare the effects of probucol and physiologic levels of ascorbate on the oxidative modification of $\mathrm{LDL}$ in both a cell-free $(2.5 \mu \mathrm{M}$ $\mathrm{Cu}^{++}$in phosphate-buffered saline) and cellular system (human monocyte macrophages in Ham's F-10 medium). Both ascorbate and probucol inhibited the oxidative modification of LDL in both systems to a similar degree as evidenced by the thiobarbituric acid-reacting substance activity, electrophoretic mobility, and degradation by macrophages. However, whereas co-incubation with physiologic levels of ascorbate resulted in a substantial preservation of the $\alpha$-tocopherol, $\gamma$-tocopherol, and $\beta$-carotene of the LDL, probucol in concentrations ranging from 10 to $80 \mu \mathrm{M}$ failed to protect these antioxidants. Thus, in addition to being as potent as probucol in inhibiting the oxidation of LDL, ascorbate in contrast preserves the endogenous antioxidants in the LDL. (J. Clin. Invest. 1991. 87:597-601.) Key words: atherosclerosis $\bullet$ lipid peroxidation - lipoproteins • macrophages • scavenger receptor
\end{abstract}

\section{Introduction}

The oxidative modification of low density lipoprotein (LDL) may provide an important link between plasma LDL and the development of atherosclerosis $(1,2)$. Available data accrued to date suggesting that oxidatively modified LDL (Ox-LDL) ${ }^{1}$ may promote atherogenesis include $(a)$ uptake by the scavenger receptor and stimulation of cholesterol esterification, $(b)$ a cytotoxic effect, e.g., to endothelium, $(c)$ increased recruitment of monocytes into the intima by its chemoattractant activity, and (d) retention of macrophages in the intima by its inhibitory

Address reprint requests to Dr. Jialal, Center for Human Nutrition, University of Texas Southwestern Medical Center, 5323 Harry Hines Boulevard, Dallas, TX 75235-9052. 1990

Received for publication 9 July 1990 and in revised form 3 October

1. Abbreviations used in this paper: Ox-LDL, oxidatively modified LDL; TBARS, thiobarbituric acid-reacting substance(s); WHHL, Watanabe heritable hyperlipidemia.

J. Clin. Invest.

(C) The American Society for Clinical Investigation, Inc.

$0021-9738 / 91 / 02 / 0597 / 05 \$ 2.00$

Volume 87, February 1991, 597-601 effect on macrophage motility (3-6). Furthermore, evidence has been presented for the occurrence of a modified form of LDL with many physical, chemical, and biological properties of Ox-LDL in arterial lesions, and antibodies against Ox-LDL recognize material in the atherosclerotic lesions of humans and LDL-receptor deficient rabbits (7-9). Hence, if Ox-LDL contributes to atherogenesis, the role of antioxidants in the prevention of the oxidative modification of LDL assumes great importance.

Probucol, 4,4'-(isopropylidenedithio) bis (2,6di-tert-butylphenol), a hypocholesterolemic drug, the structure of which is similar to the antioxidant butylated hydroxytoluene (10), inhibits the oxidative modification of LDL when tested in vitro; in addition, LDL from probucol-treated patients is highly resistant to oxidative modification (11). Moreover, in LDL receptor-deficient rabbits probucol inhibits both the rate of uptake and degradation of LDL in areas of atherosclerotic lesions and retards progression of these lesions $(12,13)$. Hence, if antioxidants can be used in the prevention of atherosclerosis, probucol is a rational choice. However, long-term use of probucol has its drawbacks. As a drug, it has various side effects $(14,15)$. It is contraindicated in certain patients (recent or progressive myocardial damage, prolonged QT interval, and syncope of cardiovascular origin) $(14,15)$. Furthermore, probucol therapy results in a substantial reduction in HDL cholesterol, the consequences of which are unknown. Thus the potential of standard dietary antioxidants on the oxidative modification of $\mathrm{LDL}$ needs to be evaluated since they are free from systemic side effects and do not appear to have any major untoward actions on the plasma lipoprotein profile. $\beta$-Carotene in vitro does not appear to inhibit the oxidative modification of $\operatorname{LDL}(5,16)$. However, it recently has been shown that ascorbate is more potent than $\alpha$-tocopherol in inhibiting the oxidation of LDL in a cell-free system $(17,18)$. Hence the present study was undertaken to compare the effects of ascorbate and probucol on the oxidative modification of LDL in both a cell-free system and a cellular system and also determine their effects on the endogenous antioxidants present in LDL.

\section{Methods}

Low density lipoprotein $(d 1.019-1.063 \mathrm{~g} / \mathrm{ml})$ was isolated by sequential ultracentrifugation from normal human plasma collected in EDTA $(1 \mathrm{mg} / \mathrm{ml})(19)$. The isolated LDL was exhaustively dialyzed against $150 \mathrm{mM} \mathrm{NaCl}, 1 \mathrm{mM}$ EDTA pH 7.4 filtered, and stored at $4^{\circ} \mathrm{C}$ under nitrogen and used within $2 \mathrm{wk}$. An aliquot of LDL was labeled with carrier-free ${ }^{125} \mathrm{I}$ by a modification of the iodine monochloride method (19). Protein was measured by the method of Lowry et al. (20) using bovine serum albumin as a standard.

Human monocytes were isolated by density-gradient centrifugation from blood derived from fasting normolipidemic subjects (21). $20 \mathrm{ml}$ of blood (anticoagulated with $10 \mathrm{U} / \mathrm{ml}$ heparin) was layered over $15 \mathrm{ml}$ of Ficoll-Paque and centrifuged at $500 \mathrm{~g}$ for $30 \mathrm{~min}$ at $23^{\circ} \mathrm{C}$. The mixed 
mononuclear cell band was removed by aspiration and the cells were washed thrice in RPMI 1640 culture medium containing $100 \mathrm{U} / \mathrm{ml}$ penicillin, $100 \mu \mathrm{g} / \mathrm{ml}$ streptomycin, and $2 \mathrm{mM}$ glutamine. The cells were plated at $2 \times 10^{6}$ mononuclear cells per $16-\mathrm{mm}$ dish or $5 \times 10^{6}$ cells per 35-mm dish (Primaria brand, Falcon Labware, Becton, Dickinson \& Co., Oxnard, CA) in the same medium. After $2 \mathrm{~h}$ of incubation at $37^{\circ} \mathrm{C}$ in $5 \% \mathrm{CO}_{2} / 95 \%$ air, nonadherent cells were removed by three washes with serum-free medium. The cells were then placed in fresh medium containing $20 \%$ autologous serum and were fed twice weekly with the same medium. Monocyte-derived macrophages were used within 10-14 d of plating. The purity of the cells was confirmed by the characteristic morphology of these monocyte-derived macrophages and the positive nonspecific esterase staining of $>95 \%$ of cells using naphthyl acetate as substrate (22). The $16-\mathrm{mm}$ well dishes were used for the degradation assay and the $35-\mathrm{mm}$ dishes were used for the oxidative modification of LDL.

$\operatorname{LDL}(200 \mu \mathrm{g} / \mathrm{ml})$ was oxidized in a cell-free system in the presence of copper $\left(\mathrm{Cu}^{++}\right)$in phosphate-buffered saline (PBS) for $24 \mathrm{~h}$ at $37^{\circ} \mathrm{C}$ $(18,23)$. The oxidative modification was performed in the absence and presence of ascorbate and probucol (dissolved in ethanol). Probucol was a gift of the Merrell Dow Chemical Company, Cincinnati, $\mathrm{OH}$. The macrophage modification of LDL was undertaken as previously described (24), except that human monocyte-derived macrophages were used instead of mouse-peritoneal macrophages. This was done to keep the system homologous since the effect of antioxidants on the oxidative modification of human LDL was being tested. In the cellular system, LDL ( $100 \mu \mathrm{g} / \mathrm{ml}$ protein) was incubated with human monocyte macrophages in Ham's F-10 media for $24 \mathrm{~h}$ at $37^{\circ} \mathrm{C}$ in the absence and presence of ascorbate and probucol. The concentration of ascorbate used in these experiments is the minimum concentration at which the oxidative modification of LDL is inhibited substantially as determined by a dose response curve (18). Although Parthasarathy et al. (11) showed that probucol in concentrations as low as $1 \mu \mathrm{m}$ had some inhibitory effect on the oxidative modification of LDL, in preliminary studies we found that only $10 \mu \mathrm{M}$ probucol reproducibly inhibited the oxidative modification of LDL. Hence, probucol at a concentration of $10 \mu \mathrm{M}$ was used. Cell-free controls (LDL in F-10 media and RPMI) were also undertaken. After the incubation, the media was aspirated, centrifuged at $1,000 \mathrm{~g}$ for $10 \mathrm{~min}$ to pellet any detached cells or debris, and the supernatant collected. In both systems oxidation was arrested by refrigeration and the addition of $200 \mu \mathrm{M}$ EDTA and $40 \mu \mathrm{M}$ butylated hydroxytolouene.

The lipid-peroxide content of the Ox-LDL was measured by a modification of the thiobarbituric acid-reacting substances (TBARS) assay of Buege and Aust as described previously (25). TBARS were expressed as malondialdehyde (MDA) equivalents using freshly diluted malondialdehyde bis (dimethyl acetal), i.e., 1,1,3,3-tetramethoxypropane as standard. LDL electrophoresis was carried out at pH 8.6 in $0.05 \mathrm{M}$ barbital buffer on $0.5 \%$ agarose gels as described (26). The gels were stained with Sudan B black.

The uptake and degradation of ${ }^{125}$ I-LDL by human monocyte-derived macrophages were measured as the appearance of trichloracetic acid-soluble radioactivity (noniodide) formed by the cells and excreted in the medium after a 5 -h incubation of ${ }^{125} \mathrm{I}-\mathrm{Ox}$-LDL with the cells in RPMI-1640 media (27). Macrophages fail to modify LDL in this medium. Degradation rates were corrected for cell-free controls incubated in parallel. The macrophages remaining in the wells after aspiration of the media were washed thrice with cold PBS, dissolved in $0.1 \mathrm{~N} \mathrm{NaOH}$ and their protein content was determined (20). Results were expressed as the amount of lipoprotein degraded per milligram of cell protein.

To determine the effect of ascorbate and probucol on the endogenous antioxidants in LDL during the oxidative modification, the concentration of $\alpha$-tocopherol, $\gamma$-tocopherol, and $\beta$-carotene in the LDL particle was quantitated. After extraction, the concentration of $\alpha$ tocopherol, $\gamma$-tocopherol, and $\beta$-carotene in the LDL samples were measured by reversed phase, high performance liquid chromatography (28).
All results were expressed as mean \pm SEM of triplicate determinations unless stated otherwise. All experiments were repeated on at least two occasions with similar results.

\section{Results}

The oxidative modification of LDL was assessed by both its enrichment in lipid peroxides (TBARS assay) and its increased negative charge (electrophoretic mobility). When LDL was incubated with $\mathrm{Cu}^{++}$for $24 \mathrm{hs}$, both ascorbate (40 and $\left.60 \mu \mathrm{M}\right)$ substantially inhibited the oxidative modification of LDL as reflected by both the electrophoretic mobility and TBARS content as depicted in Table I; however, whereas $5 \mu \mathrm{M}$ probucol did not significantly inhibit the oxidative modification of LDL, $10 \mu \mathrm{M}$ probucol had a significant effect. Hence, in all other experiments $10 \mu \mathrm{M}$ probucol was used. Further, by inhibiting the oxidative modification of LDL, ascorbate and probucol ( 10 $\mu \mathrm{M})$ substantially decreased uptake and degradation of ${ }^{125} \mathrm{I}$ LDL by the macrophages (Table I).

Human monocyte-derived macrophages clearly modify LDL as evidenced by the increased lipid-peroxide content and increased negative charge of the modified LDL and increased uptake by the scavenger-receptor mechanism. Both ascorbate $(40 \mu \mathrm{M})$ and probucol $(10 \mu \mathrm{M})$ inhibited the macrophage-mediated oxidation of LDL as evidenced by the electrophoretic mobility and TBARS content; ascorbate decreased the TBARS by $90 \%$ whereas probucol decreased the TBARS by $80 \%$ as shown in Fig. 1. By inhibiting the oxidative modification of LDL, both ascorbate and probucol prevented its uptake and degradation by a second set of cultured macrophages (Fig. 2).

Table I. Effect of Ascorbate and Probucol on the $\mathrm{Cu}^{++}$-catalyzed Oxidation of $L D L$

\begin{tabular}{lccc}
\hline & TBARS & $\begin{array}{c}\text { Electrophoretic } \\
\text { mobility* }\end{array}$ & 125I-LDL degradation \\
\hline & $\begin{array}{c}\text { nmol/mg } \\
\text { protein }\end{array}$ & & ng/mg cell protein \\
& $2.0 \pm 0.4$ & 1.0 & $227 \pm 23$ \\
LDL & $46 \pm 0.3$ & 4.3 & $2,087 \pm 141$ \\
$\begin{array}{l}\text { OX-LDL } \\
\text { OX-LDL + probucol } \\
(5 \mu \mathrm{M})\end{array}$ & $40 \pm 0.8$ & 3.6 & $2,058 \pm 151$ \\
$\begin{array}{l}\text { OX-LDL + probucol } \\
(10 \mu \mathrm{M})\end{array}$ & $8.0 \pm .12$ & 1.3 & $157 \pm 13$ \\
$\begin{array}{l}\text { OX-LDL + ascorbate } \\
(40 \mu \mathrm{M})\end{array}$ & $6.0 \pm 0.1$ & 1.3 & $216 \pm 24$ \\
$\begin{array}{l}\text { OX-LDL + ascorbate } \\
(60 \mu \mathrm{M})\end{array}$ & $3.8 \pm 0.1$ & 1.0 & $197 \pm 18$ \\
\hline
\end{tabular}

${ }^{125} \mathrm{I}-\mathrm{LDL}\left(200 \mu \mathrm{g} / \mathrm{ml}\right.$ protein) was oxidized with $2.5 \mu \mathrm{M} \mathrm{Cu}^{++}$in PBS for $24 \mathrm{~h}$ at $37^{\circ} \mathrm{C}$ in the absence and presence of ascorbate and probucol at the concentration shown. The reaction was arrested by refrigeration and the addition of $200 \mu \mathrm{M}$ EDTA and $40 \mu \mathrm{M}$ butylated hydroxytoluene. Thereafter an aliquot was subjected to agarose gel electrophoresis and assayed for TBARS activity as described in Methods. Also, an aliquot was then added to $16-\mathrm{mm}$ dishes of human macrophages to yield a final concentration of $10 \mu \mathrm{g} / \mathrm{ml}$. After a 5-h incubation at $37^{\circ} \mathrm{C}$, trichloracetic acid-soluble radioactivity, corrected for cell-free controls, was determined.

* Electrophoretic mobility is expressed as migration relative to native LDL. 
(A)

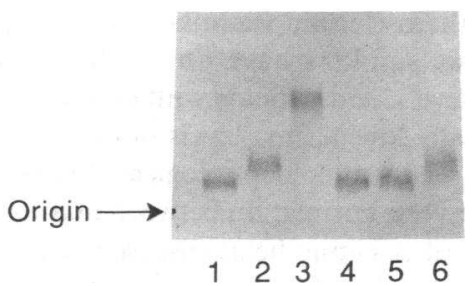

(B)

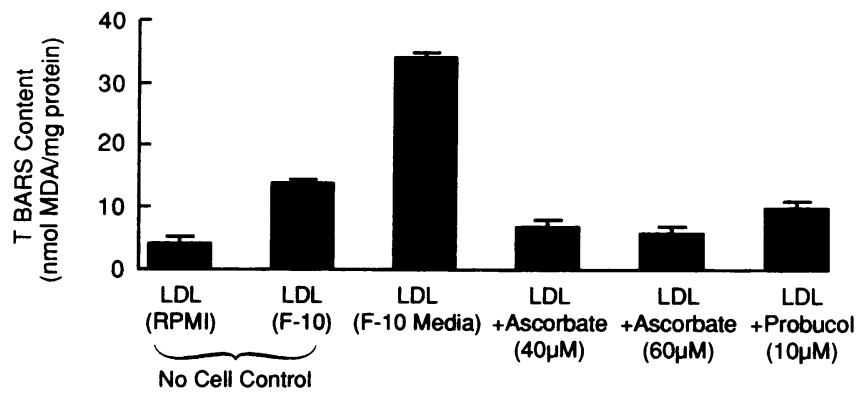

Figure 1. Effect of ascorbate and probucol on the macrophage modification of LDL. LDL $(100 \mu \mathrm{g} / \mathrm{ml})$ was incubated with human monocyte-derived macrophages (35-mm dishes) in Ham's F-10 media for $24 \mathrm{~h}$ at $37^{\circ} \mathrm{C}$ in the absence and presence of ascorbate and probucol. Cell-free controls of LDL in either F-10 or RPM1-1640 media were also undertaken. After the incubation, the reaction was arrested as described in the legend to Table $I$ and the media were centrifuged. An aliquot of the supernatant was subjected to agarose gel electrophoresis $(A)$ and assayed for TBARS activity $(B)$ as described in Methods.

Previously, it has been shown in other systems that ascorbate can reduce the tocopheroxyl radical and hence regenerate tocopherol (29-31). To investigate if such a situation, obtained with respect to antioxidant effect of ascorbate on LDL, the effect of both ascorbate and probucol on the endogenous antioxidants present in the LDL particle was determined during copper-catalyzed oxidation of LDL. Oxidative modification of LDL in this system, as evidenced by the increased negative charge and increased lipid-peroxide content, resulted in an inability to detect $\alpha$-tocopherol and $\beta$-carotene, and an $87.5 \%$ reduction in $\gamma$-tocopherol content of LDL, compared to the control LDL (Table II). Co-incubation of LDL with ascorbate during similar oxidative conditions inhibited LDL oxidation as evidenced by the decreased TBARS activity and electrophoretic mobility, and resulted in a preservation of the endogenous antioxidants in the LDL particle ( $\beta$-carotene $95 \%, \beta$-tocopherol $88 \%$, and $\alpha$-tocopherol $69 \%$ of control). However, whereas probucol $(10 \mu \mathrm{M})$ also inhibited the oxidation of LDL to a similar degree as ascorbate, it failed to preserve the endogenous antioxidants in LDL. Since only a single concentration of probucol $(10 \mu \mathrm{M})$ was used in this study, it could be argued that higher concentrations of probucol would result in a preservation of the endogenous antioxidants in LDL. Hence, LDL was incubated with higher concentrations of probucol, similar to

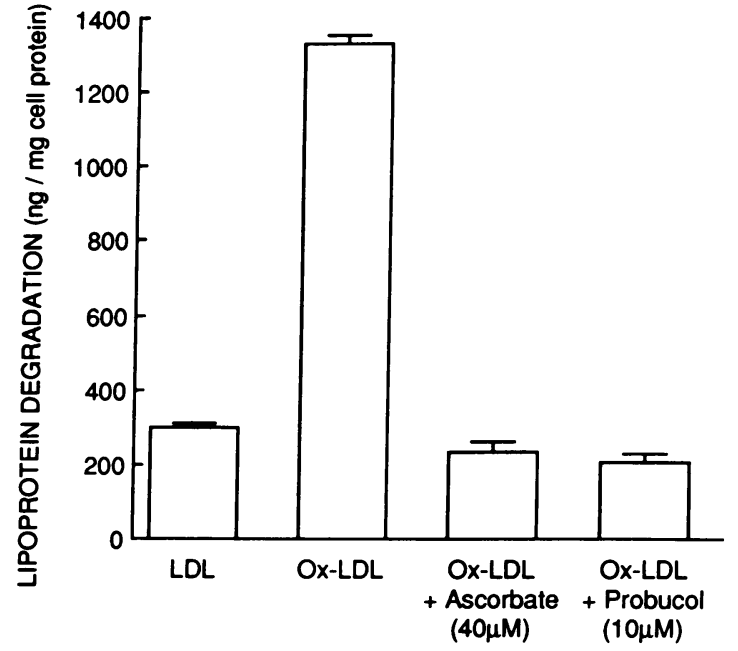

Figure 2. Effect of ascorbate and probucol on the degradation of ${ }^{125} \mathrm{I}$ LDL by human macrophages ${ }^{125} \mathrm{I}-\mathrm{LDL}(100 \mu \mathrm{g} / \mathrm{ml})$ was incubated with human monocyte-derived macrophages (35-mm dishes) in Ham's F-10 media for $24 \mathrm{~h}$ at $37^{\circ} \mathrm{C}$ in the absence and presence of ascorbate and probucol. After the incubation, the reaction was arrested as described in the legend to Fig. 1. An aliquot of the supernatant was then added to a second set of macrophages (16-mm dishes) to yield a final concentration of $10 \mu \mathrm{g} / \mathrm{ml}$ in RPM1 media. After a 24-h incubation, trichloracetic acid-soluble radioactivity corrected for cell-free controls was determined.

that attained in the plasma of patients treated with $1.0 \mathrm{~g} / \mathrm{d}$ of probucol $(32,33)$, during copper-catalyzed oxidation. Once again, while the higher concentrations of probucol more effectively reduced LDL oxidation, they failed to preserve the endogenous antioxidants (Table III). Similar findings with respect to the preservation of the endogenous antioxidants in LDL with ascorbate but not probucol were obtained with macrophage modification of LDL (data not shown). Probucol did not interfere with the determination of the tocopherols or $\beta$-carotene by high-pressure liquid chromatography.

Table II. Effect of Ascorbate and Probucol on the Antioxidant Content of $L D L$ during Oxidation

\begin{tabular}{|c|c|c|c|c|}
\hline & LDL & Ox-LDL & $\begin{array}{c}\text { Ox-LDL } \\
+ \text { ascorbate } \\
(50 \mu \mathrm{M})\end{array}$ & $\begin{array}{c}\text { Ox-LDL } \\
+ \text { probucol } \\
(10 \mu \mathrm{M})\end{array}$ \\
\hline \multicolumn{5}{|l|}{ TBARS } \\
\hline (nmol/mg protein) & 1.6 & 37.0 & 3.3 & 7.5 \\
\hline Electrophoretic mobility* & 1 & 5.0 & 1.3 & 1.6 \\
\hline \multicolumn{5}{|l|}{$\alpha$-Tocopherol } \\
\hline (nmol/mg protein) & 3.9 & ND & 2.7 & ND \\
\hline \multicolumn{5}{|l|}{$\gamma$-Tocopherol } \\
\hline (nmol/mg protein) & 2.4 & 0.3 & 2.1 & ND \\
\hline \multicolumn{5}{|l|}{$\beta$-Carotene } \\
\hline (pmol/mg protein) & 28.2 & ND & 26.9 & ND \\
\hline
\end{tabular}

nd, not detectable.

* Electrophoretic mobility is expressed as migration relative to native LDL. 
Table III. Effect of Increasing Concentrations of Probucol on the Antioxidant Content of LDL during Oxidation

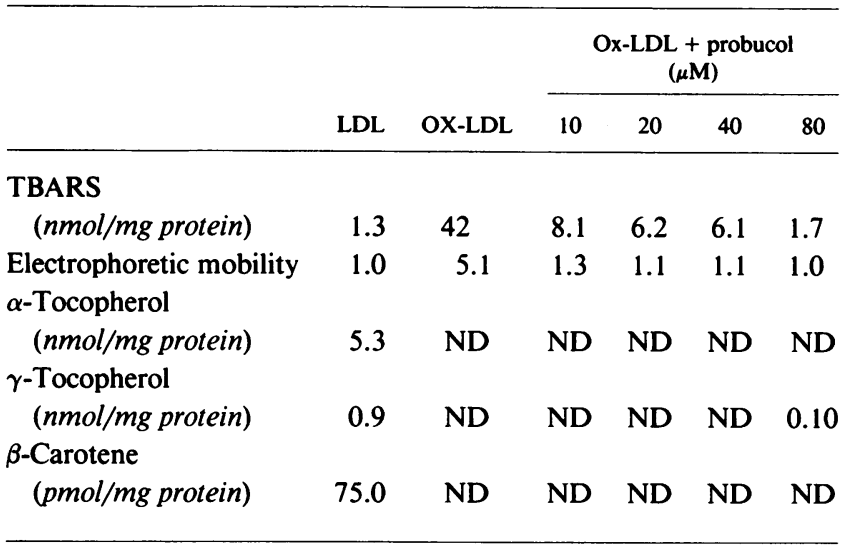

\section{Discussion}

The best appreciated function of ascorbate is its role as a cofactor for prolyl and lysl hydroxylases in the biosynthesis of collagen (34). However, ascorbate also is a water-soluble, chainbreaking antioxidant $(35,36)$. It reacts directly with superoxide, hydroxyl radicals, and singlet oxygen (37-39). Furthermore, it interacts with the tocopheroxyl radical resulting in the generation of tocopherol (29-31). Also, it has been demonstrated that ascorbate is the most effective aqueousphase antioxidant in human plasma incubated with a watersoluble radical initiator (40). Since the oxidation of LDL appears to be an extracellular event, the effect of a physiologic, water-soluble antioxidant on this process needs to be determined. Hence the effect of ascorbate on the oxidative modification of LDL was tested and compared to that of probucol, since it has been shown previously that probucol also prevents the progression of atherosclerosis in Watanabe heritable hyperlipidemia (WHHL) rabbits $(11,12)$. Since probucol seemingly does not directly prevent foam cell transformation of macrophages in WHHL rabbits or mice $(41,42)$, the action of probucol against atherogenesis in WHHL rabbits most likely is due to its inhibitory effect on the oxidative modification of LDL (41). In the present study, ascorbate was as potent as probucol in inhibiting the oxidative modification of LDL mediated by a transition metal or by human macrophages. By inhibiting the oxidative modification of LDL, both ascorbate and probucol prevented LDL uptake by the scavenger-receptor mechanism of macrophages. This action should prevent cholesteryl ester accumulation and hence foam cell formation (1). The cultured human monocyte-derived macrophage was chosen as the cellular system for oxidative modification because, in addition to being readily accessible, the oxidative modification resulting from incubation of LDL with these cells allows recognition by the scavenger-receptor mechanism. A biological characteristic of oxidatively modified LDL is recognition by the scavenger receptor mechanism (1). LDL that is oxidatively modified by activated monocytes which are also an easily accessible source of human cells does not appear to be recognized by the scavenger receptor mechanism (43).

The concentration of ascorbate used in these studies to in- hibit LDL oxidation $(40-60 \mu \mathrm{M})$ is well within the normal plasma range (23-85 $\mu \mathrm{M})(44-46)$. In a recent study, it was shown that ascorbate levels were significantly lower in the aorta of patients with atherosclerotic vascular disease compared to controls (47). Also, smokers have an $\sim 40 \%$ reduction in plasma ascorbate levels, and patients with coronary artery disease have abnormally low plasma levels of ascorbate (48-50). In addition, cross-sectional epidemiological studies in Europe have revealed an inverse correlation between plasma ascorbate and the incidence of ischemic heart disease (51). All of these findings raise the possibility that lower levels of ascorbate in the arterial wall plays a role in development of atherosclerosis. The data in the present study suggest that depleted levels of ascorbate in the arterial wall might predispose the LDL to oxidative modification by the macrophages, smooth muscle cells, and endothelial cells, and thereby promote atherogenesis.

Although the effect of probucol to inhibit the oxidative modification of LDL has been studied $(11,12)$, its ability to protect endogenous antioxidants of the LDL particle has not been examined. In the present study, whereas both ascorbate and probucol inhibited the oxidative modification of LDL to a similar degree, their effect on the endogenous antioxidants in LDL were very different. Ascorbate largely preserved the endogenous antioxidants in LDL, whereas probucol failed to preserve them. The effectiveness of probucol to inhibit macrophage uptake of LDL may be related to protection of the surface reactive amino groups (mainly lysine) against oxidation (52). However, McLean and Hagaman (52) showed that in vitro incubation of LDL with probucol does not completely prevent oxidation since some fluorescent products of LDL oxidation could be detected. Since probucol does not completely inhibit the production of fluorescent oxidation products, but completely inhibits the decrease in reactive amino groups on the surface of LDL, these workers proposed that probucol prevented a secondary oxidation event that results in modification of lysine residues on the surface of LDL. Hence the findings in the present report would support this notion that probucol does not completely inhibit LDL oxidation since the endogenous antioxidants in LDL were completely consumed.

However, incubation of LDL with ascorbate in contrast largely preserved the natural antioxidants in LDL. This finding accords with the observations of Frei et al. (40) who used a different system. They demonstrated that addition of ascorbate $(100 \mu \mathrm{M})$ to plasma incubated with a water-soluble radical initiator resulted in a transient protection of the endogenous antioxidants including $\alpha$-tocopherol, bilirubin, and urate. This action cannot be attributed to the ability of ascorbate to reduce the tocopheroxyl radical to tocopherol since both the tocopherols and beta carotene were preserved. Therefore, ascorbate seemingly acts at a proximal step in the oxidation process, scavenging the free radical(s) and protecting the LDL particle from significant oxidative attack. In other words, ascorbate would appear to behave as a sacrificial antioxidant.

Although the data of the present study cannot be translated directly to the in vivo situation, it should be pointed out that in addition to ascorbate functioning as a chain-breaking antioxidant, ascorbate supplementation in animals leads to increased plasma and tissue vitamin E levels (53). Hence, if antioxidant supplementation emerges as an important element in prevention of atherosclerosis, ascorbate will have to be given serious consideration as one component of this regimen. 


\section{Acknowledgments}

The authors thank Kimberly White for technical assistance, Linda Prichard for manuscript preparation, and Drs. H. N. Bhagavan and E. P. Norkus for critical discussions.

This work was supported by a grant from Hoffmann-La Roche, the Moss Heart Foundation, and the Southwestern Medical Foundation, and by grant HL-29252 from the National Institutes of Health.

\section{References}

1. Steinberg, D., S. Parthasarathy, T. E. Carew, J. C. Khoo, and J. L. Witztum 1990. Beyond cholesterol: modification of low density lipoproteins that increase its atherogenicity. N. Engl. J. Med. 320:915-924.

2. Jurgens, G., H. Hoff, G. Chisolm, and H. Esterbauer. 1987. Modification of human serum LDL by oxidation: characterization and pathophysiological implications. Chem. Phys. Lipids. 45:315-336.

3. Henriksen, T., E. M. Mahoney, and D. Steinberg. 1981. Enhanced macrophage degradation of LDL previously incubated with cultured endothelial cells. Proc. Natl. Acad. Sci. USA. 78:6499-6503.

4. Henriksen, T., E. M. Mahoney, and D. Steinberg. 1983. Enhanced macrophage degradation of biologically modified low density lipoprotein. Arteriosclero sis. 3:149-159.

5. Morel, D. W., J. R. Hessler, and G. M. Chisolm. 1983. Low density lipoprotein cytotoxicity induced by free radical peroxidation of lipid. J. Lipid Res. 24:1070-1076.

6. Quinn, M. T., S. Parthasarathy, L. G. Fong and D. Steinberg. 1987. Oxidatively modified low density lipoproteins: a potential role in recruitment and retention of monocyte macrophages during atherogenesis. Proc. Natl. Acad. Sci. USA. 84:2995-2998.

7. Haberland, M. E., D. Fong, and L. Cheng. 1988. Malondialdehyde-altered protein occurs in atheroma of Watanabe heritable hyperlipidemic rabbits. Science (Wash. DC). 241:215-218.

8. Palinski, W., M. Rosenfeld, S. Yla-Herttuala, G. Gurtner, S. Socher, S Butler, S. Parthasarathy, T. E. Carew, D. Steinberg, and J. Witztum. 1989. Low density lipoprotein undergoes oxidative modification in vivo. Proc. Natl. Acad. Sci. USA. 86:1372-1376.

9. Yla-Herttuala, S., W. Palinski, M. Rosenfeld, S. Parthasarathy, T. E. Carew, S. Butler, J. Witztum, and D. Steinberg. 1989. Evidence for the presence of oxidatively modified LDL in atherosclerotic lesions of rabbit and man. J. Clin. Invest. 284:1086-1095.

10. Steinberg, D., S. Parthasarathy, and T. E. Carew. 1988. In vivo inhibition of foam cell development by probucol in Watanabe rabbits. Am. J. Cardiol. $62: 6 \mathrm{~B}-12 \mathrm{~B}$

11. Parthasarathy, S., S. Young, J. L. Witztum, R. C. Pittman, and D. Steinberg. 1986. Probucol inhibits oxidative modification of low density lipoprotein. $J$. Clin. Invest. 77:641-644.

12. Kita, T., Y. Nagano, M. Yokode, K. Ishii, N. Kume, A. Ooshima, H. Yoshida, and C. Kawai. 1987. Probucol prevents the progression of atherosclerosis in Watanabe heritable hyperlipidemic rabbit, an animal model for familial hypercholesterolemia. Proc. Natl. Acad. Sci. USA. 84:5928-5931.

13. Carew, T. E., D. Schwenke, and D. Steinberg. 1987. Antiatherogenic effect of probucol unrelated to its hypocholesterolemic effects. Proc. Natl. Acad. Sci. USA. 84:7725-7729.

14. Physicians Desk Reference. 44th edition. 1990. Medical Economics Company, Oradell, NJ. 1469-1471.

15. Buckley, M. T., K. L. Goa, A. H. Price, and R. H. Brogden. 1989. Probucol: a reappraisal of its pharmacological properties and therapeutic use in hypercholesterolemia. Drugs. 37:761-800.

16. van Hinsberg V. W., M. Scheffer, L. Havekes, and H. J. Kempen 1986. Role of endothelial cells and their products in the modification of low density lipoproteins. Biochim. Biophys. Acta. 878:49-64.

17. Esterbauer, H., G. Striegl, H. Puhl, and M. Rotheneder. 1989. Continuous monitoring of in vitro oxidation of human low density lipoprotein. Free Radical Res. Commun. 6:67-75.

18. Jialal, I., G. L. Vega, and S. M. Grundy. 1990. Physiologic levels of ascorbate inhibit the oxidative modification of low density lipoprotein Atherosclero sis. 82:185-191.

19. Grundy, S. M., and G. L. Vega. 1985. Influence of mevinolin on metabolism of low density lipoproteins in primary moderate hypercholesterolemia. $J$. Lipid Res. 26:1464-1475.

20. Lowry, O. H., N. J. Rosebrough, A. Farr, and R. J. Randall. 1951. Protein measurement with the folin phenol reagent. J. Biol. Chem. 193:265-275.

21. Aviram, M., E. L. Bierman, and A. Chait. 1988. Modification of low density lipoprotein by lipoprotein lipase or hepatic lipase induces enhanced uptake and cholesterol accumulation. J. Biol. Chem. 263:15416-15422.

22. Yam, L. T., C. Y. Li, and W. H. Crosby, 1971. Cytochemical identification of monocytes and granulocytes. Am. J. Clin. Pathol. 55:283-290.

23. Steinbrecher, U. P., J. L. Witztum, S. Parthasarathy, and D. Steinberg.
1987. Decrease in reactive amino groups during oxidation of endothelial cell modification of LDL. Arteriosclerosis. 7:135-143.

24. Parthasarathy, S., D. Printz, D. Boyd, L. Joy, and D. Steinberg. 1986. Macrophage oxidation of low density lipoprotein generates a modified form recognized by the scavenger receptor. Arteriosclerosis. 6:505-510.

25. Heinecke, J., L. Baker, H. Rosen, and A. Chait. 1986. Superoxide mediated modification of LDL by arterial smooth muscle cells. J. Clin. Invest. 77:757-761.

26. Noble, R. P. 1968. Electrophoretic separation of plasma lipoproteins in agarose gels. J. Lipid Res. 9:693-700.

27. Bierman, E. L., O. Stein, and Y. Stein. 1974. Lipoprotein uptake and metabolism by rat aortic smooth muscle cells in tissue culture. Circ. Res. 35:136 150.

28. Stacewicz-Sapunrakis, M., P. Bowen, J. Kendall, and M. Burgess. 1987 Simultaneous determination of serum retinal and various carotenoids. J. Micronutr. Anal. 3:27-45

29. Packer, J. E., T. F. Slater, and R. L. Wilson. 1979. Direct observation of a free radical interaction between vitamin $\mathrm{E}$ and vitamin $\mathrm{C}$. Nature (Lond.). 278:737-738.

30. Doba, T., G. W. Burton, and K. U. Ingold. 1985. Antioxidant and co-antioxidant activity of vitamin C. Biochim. Biophys. Acta. 835:298-303.

31. Niki, E. 1987. Antioxidants in relation to lipid peroxidation. Chem. Phys. Lipids. 44:227-253.

32. Dachet, C., B. Jacotot, and J. Buxtorf. 1985. The hypolipidemic action of probucol. Atherosclerosis. 58:261-268.

33. Fellin, R., A. Gasparatto, G. Valerio, M. R. Baiocchi, R. Padrini, S. Lamon, E. Vitale, G. Baggio, and G. Crepaldi. 1986. Effect of probucol treatment on lipoprotein cholesterol and drug levels in blood and lipoproteins in familial hypercholesterolemia. Atherosclerosis. 59:47-56.

34. Levine, M. 1986. New concepts in the biology and biochemistry of ascorbic acid. N. Engl. J. Med. 314:892-902.

35. Bendich, A., L. J. Machlin, O. Scandurra, G. W. Burton, D. Wayner. 1986. The antioxidant role of vitamin C. Adv. Free Radicals Biol. Med. 2:419444.

36. Niki, E., T. Saito, and Y. Kamiya. 1983. The role of vitamin C as an antioxidant. Chem. Lett. 5:631-632.

37. Bodannes, R. S., and P. C. Chan. 1979. Ascorbic acid as a scavenger of singlet oxygen. FEBS (Fed. Eur. Biochem. Soc.) Lett. 105:195-196.

38. Nishikimi, M. 1975. Oxidation of ascorbic acid with superoxide anion generated by the xanthine-xanthine oxidase system. Biochem. Biophys. Res. Commun. 63:463-468.

39. Bielski, B. H. 1982. Chemistry of ascorbic acid radicals. Adv. Chem. Ser. 200:81-100.

40. Frei, B., L. England, and B. N. Ames. 1989. Ascorbate is an outstanding antioxidant in human blood plasma. Proc. Natl. Acad. Sci. USA. 86:6377-6381.

41. Nagano, Y., T. Kita, M. Yokode, K. Ishii, N. Kume, H. Otani, H. Arai, and C. Kawai. 1989. Probucol does not affect lipoprotein metabolism in macrophages of Watanabe heritable hyperlipidemic rabbits. Arteriosclerosis. 9:453461 .

42. Ku, G., K. Schroeder, L. Schmidt, R. L. Jackson, and N. Doherty 1990. Probucol does not alter acetylated low density lipoprotein uptake by murine peritoneal macrophages. Atherosclerosis. 80:191-197.

43. Hiramatsu, K, H. Rosen, J. Heinecke, G. Wolfbauer, and A. Chait 1987. Superoxide initiates oxidation of low density lipoprotein by human monocytes. Arteriosclerosis. 7:55-60.

44. Jaffe, G. M. 1984. Vitamin C. In Handbook of Vitamins. L. J. Machlin, editor. Marcel Dekker, Inc., New York. 199-244.

45. Case Records of the Massachusetts General Hospital. 1986. Normal reference values. $N$. Engl. J. Med. 314:39-49.

46. Sauberlich, H. E. 1975. Vitamin c status: methods and findings Ann $N, Y$ Acad. Sci. 258:438-450.

47. Dubick, M., G. Hunter, S. Casey, and C. Keen. 1987. Aortic ascorbic acid trace elements and superoxide dismutase activity in human an aneurysmal and occlusive disease. Proc. Soc. Exp. Biol. Med. 184:138-143.

48. Pelletier, O. 1977. Vitamin C and tobacco. Int. J. Vitam. Nutr. Res. 16:147-169.

49. Duthie, G., J. Arthur, W. James, and H. Vint, 1989. Antioxidant status of smokers and non-smokers. Ann. N. Y. Acad. Sci. 570:435-438.

50. Ramirez, J., and N. Flowers. 1980. Leukocyte ascorbic acid and its relationship to coronary artery disease in man. Am. J. Clin. Nutr. 33:2079-2087.

51. Gey, K. F., G. Brubacher, and B. Stahelin. 1987. Plasma levels of antioxidant vitamins in relation to ischemic heart disease and cancer. Am. J. Clin. Nutr. 45:1368-1377.

52. McLean, L. R., and K. A. Hagaman. 1989. Effect of probucol on the physical properties of low density lipoproteins oxidized by copper. Biochemistry. 28:321-327.

53. Bendich, A., P. D'Apolito, E. Gabriel, and L. J. Machlin. 1984. Interaction of dietary vitamin $C$ and vitamin $E$ on guinea pig immune responses to mitogens. J. Nutr. 114:1588-1593. 